\title{
A path model of antecedents of green purchase behaviour among Indian consumers
}

\author{
Vaishali Sethi* \\ I.K. Gujral Punjab Technical University, \\ Punjab, India \\ and \\ Vivekananda Institute of Professional Studies, \\ GGSIPU, \\ New Delhi, India \\ Email: vaishali.nanda86@gmail.com \\ *Corresponding author

\section{Manvinder Singh Tandon} \\ I.K. Gujral Punjab Technical University, \\ Punjab, India \\ and \\ RIMT University \\ Mandi Gobindgarh, Punjab, India \\ Email: dr.manvinder_tandon@yahoo.com
}

\section{Kirti Dutta}

G.L. Bajaj,

Greater Noida, India

Email: duttakirti@yahoo.co.in

\begin{abstract}
The study aims to recommend and investigate a model of the outcomes of explicit various constructs on the frequency of green purchase behaviour. Environmental concern, Green advertisement, Perceived quality of green products, word of mouth, motivation to comply and social influence are operationalised by a path model hypothesising effects of these antecedents on attitude and subjective norm leading to purchase intention and finally the purchase behaviour of green products. The research employs survey based method to check a theoretically grounded set of hypothesis. A well-structured questionnaire was administered to collect responses from 501 respondents. The data was analysed using SPSS and AMOS with techniques of CFA and SEM to get the results. This study indicates that positive attitude toward green products leads to the intention of consumers to purchase them. The findings can help the marketers to formulate their policy with regard to actions which would enhance the purchase and usage behaviour of the consumers towards green products.
\end{abstract}

Keywords: green marketing; green purchase behaviour; attitude; environmental concern; green advertising; subjective norm. 
Reference to this paper should be made as follows: Sethi, V., Tandon, M.S. and Dutta, K. (2018) 'A path model of antecedents of green purchase behaviour among Indian consumers', Int. J. Public Sector Performance Management, Vol. 4, No. 1, pp.21-44.

Biographical notes: Vaishali Sethi is currently an Assistant Professor in the Vivekananda Institute of Professional Studies, GGSIPU, New Delhi. She graduated from a very renowned school of the Capital, Bal Bharti Public School. She received her BSc in Mathematics $(\mathrm{H})$ from the Kirorimal College, Delhi University. Thereafter, completing her post-graduation, PGDBM (equivalent to MBA from AIU) from the NIILM-CMS in the field of marketing, she passed the UGC NET in Management exam in December 2011. Presently, she is pursuing her $\mathrm{PhD}$ degree from the Punjab Technical University, Kapurthala in the field of green marketing. She is extremely dynamic and sparkling professional with eight years of rich and productive experience in corporate and educational sector. She possesses excellent communication and organisational skills and excellent relationship builder with students, faculty, and administration.

Manvinder Singh Tandon has a rich experience with more than 20 years in academics. He has more than 40 research papers in the field of management and presently working as a Director in RIMT College.

Kirti Dutta has a rich experience of around 23 years including 11 years of corporate experience. She is a prolific researcher and writer. She is currently working on many national and international projects in the domain of branding, advertising and services marketing. She has co-authored more than 50 research papers that have been published in national and international journals. Her first book was published by Oxford University Press in 2009. Her second book titled Brand Management was again published by the Oxford University Press in 2012. Her third text book titled Integrated Marketing Communications was published by Oxford University Press in December 2016.

\section{Introduction}

There has been a growing concern on environmental issues internationally. Today's customers have commenced to recognise that their purchasing behaviour surely can cause a large effect on environment. Therefore, being socially accountable with the aid of presenting environmentally friendly products and services have to be a practice of any companies who want to sustain an aggressive benefit in the business world (Rahbar and Abdul Wahid, 2011). Environmental troubles as so important that many governmental agencies round the world were looking to prepare essential laws and rules to protect the environment. Meanwhile, consumers are paying more attention to purchase eco-friendly products and materials. They are more and more willing to purchase environmentally friendly or so called green products even though that merchandise are often more pricey (Sua et al., 2012).

The latest situation for the consequences of world climate exchange has sensitised the purchaser to look for the well-being of destiny generations. The required responses to the heightened environmental worries are, therefore, not sincerely limited to the environmental regulations and government tasks. Instead, organisations too want to 
commit to the environmental issues of their business decisions and be part of the bandwagon termed green motion. However, the motivation to adopt the concept of green motion of their businesses rests on purchasers demonstrating an excessive diploma of environmental mind-set which translates into green purchase behaviour (PB). The improved demand for green products could act as a pressure factor on enterprise corporations to turn green and start marketing green products.

An important factor for considering environmental issues in business decisions are identification and targeting of 'green consumer segments', which show evidence of some kind of environment friendly behaviour in their use and consumption-related activities. Exploring the antecedents' influential in formulation of green purchasing behaviour is, therefore, of meticulous interest to researchers to propose the market viability of green product alternatives and to categorise lucrative green segments.

This paper will focus specifically on the PB of green products. In addition, the purpose of this study is to seek to broaden the understanding of what factors influence on intentions of purchasing green products by consumers further leading to actual PB.

\section{Review of literature}

The term - green marketing includes the marketing sports of an enterprise wherein all marketing undertakings are taken underneath the environmental difficulty structures (Alsmadi, 2007). In addition, green marketing is the marketing technique where entrepreneur's intention is to discover environmental responsive customers. Displaying and positioning green merchandise in the front of the customers, is taken into account as consumer product advertising and marketing [Leigh (1988) mentioned in McDaniel and Rylander (1993)]. The term - green product is used to describe product, which are not dangerous for the environment or merchandise which are environment pleasant. Chemical compositions of the products are also surroundings friendly and suitable to recycle (Alsmadi, 2007).

The theory of planned behaviour (TPB) forms the theoretical framework of this research because it offers a clearly defined structure/model that allows the investigation of the influence that attitudes, personal and cultural determinants and volitional control have on consumers' intentions to buy green products.

\subsection{Theory of planned behaviour}

The theory of reasoned action (TRA) propounded by Ajzen and Fishbein (1977) paved the path for the TPB by Ajzen (1991). The TPB has been used in this study for examining the purchasing behaviour towards green products. The TPB enables us with a complete framework for exploring the factors which influence the decision to engage in behaviour related to environmental issues such as recycling (Chan, 2001) and the same can be applied in systematically understanding different factors affecting the PB for environmentally friendly products.

According to the TRA, intention of undertaking or not undertaking the behaviour is the direct predecessor to the behaviour. The intention under discussion is often a result of actions undertaken by individual to evaluate the favourable or unfavourable performance of the behaviour. In many cases, it enunciates disposition of the attitude and the 
subjective norm wherein the subjective norm is basically the perception formed by the individual about undertaking or not undertaking that behaviour due to the social pressure. One prominent assumption of TRA is that behaviour under consideration is volitional in nature, i.e., person can decide whether he or she performs that behaviour or not (Ajzen, 1991). Although true in many cases, behaviour may also depend on other factors such as availability of appropriate opportunities and resources which collectively correspond to the people's actual control over the behaviour (Liska, 1984). The TPB is one step ahead of the TRA in the sense that it takes care of the original model's limitation to deal with incomplete volitional control (Ajzen, 1991). TPB includes a third variable known as perceived behavioural control (PBC) which indicates the ability of a person to undertake the behaviour under consideration under the assumption that individual behaves in a rational manner considering the ramification of his or her actions (Ramayah et al., 2012). In fact, PBC manifests the difficulty and controllability to execute specific behaviour (Ajzen, 1985).

Figure 1 Theory of planned behaviour

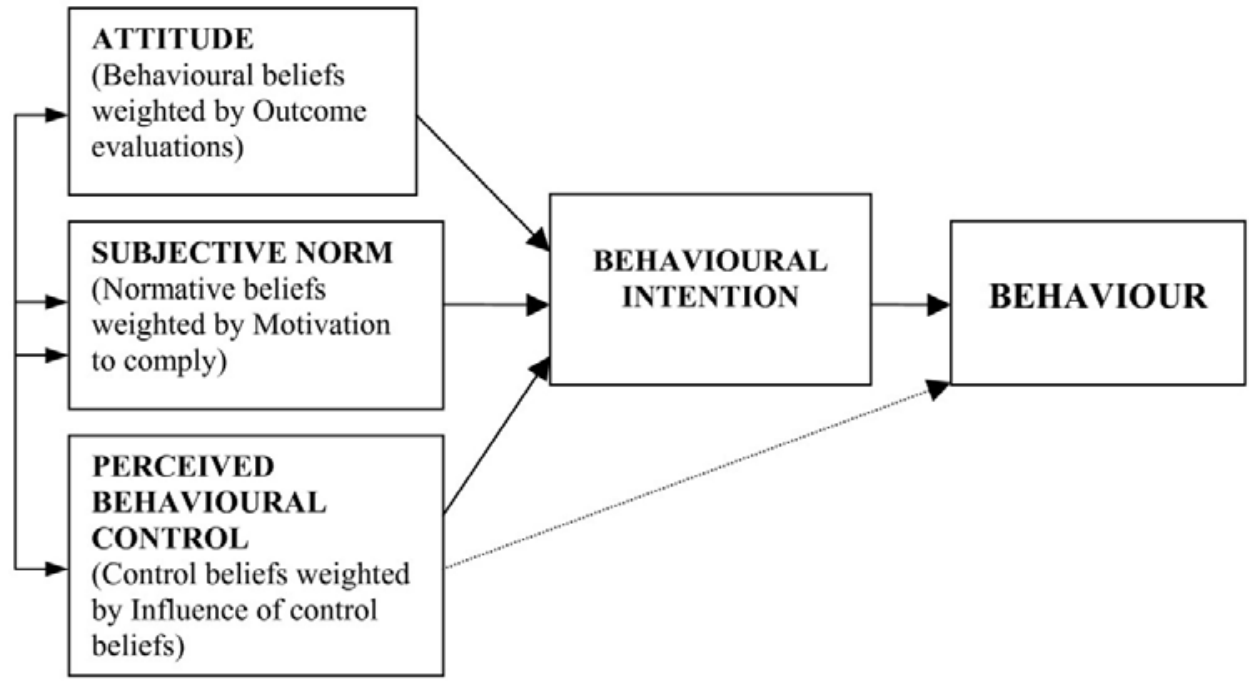

Source: Ajzen (1991)

Symbolically, the TPB model is presented in Figure below where it is illustrated that each of the determinants of intention, i.e., attitude to behaviour (AB), subjective norm (SN) and perceived control (PBC) is, in turn, determined by underlying belief structures.

The know-how of the intention, attitudes closer to the behaviour, subjective norms, PBC and peripheral persuasion can help to exposed the special aspects of the behaviour or apprehend better the conduct, if you want to then help the marketers in designing the marketing strategies to be capable of convincing the customers to make the purchases of the products.

In order to understand the $\mathrm{PB}$ of green products, various factors like green advertising (GA), environmental concern (EC) and perceived quality of green products (PQGP) will be studied intensively to find their impact on the attitude of consumers towards green products which leads to intent of purchasing them. 


\subsection{Attitude}

Fishbein and Ajzen (1975) defined attitude as one's positive/negative evaluation of a specific behaviour. Hoyer and Macinnis (2001) also considered attitude to be the positive or negative evaluation of an object, action, issue, or person. Attitudes are sets of beliefs about a certain object or an act, which may translate into intention to carry out the act. Intention on the other hand is a determination to act in a certain way (Ramayah et al., 2010). Attitudes are the favourable or unfavourable evaluation an individual forms of a specified behaviour. Attitudes impact the intentions held and the more favourable the attitude, the bigger the intention to perform the behaviour will be. In addition, attitudes are predictors of PIs and consequently PB. Moreover, attitudes are necessary, as consumers require an understanding of their attitudes and motivations in order to overcome the perceived purchase barriers they face (Smith and Paladino, 2010).

The attitudes of consumers to purchase green products are made up of their beliefs, knowledge and concern towards the concept of green products, which they accumulate from their lifetime. Recognising the seriousness of environmental problems possibly caused by excessive use of energy and non-renewable natural resources, copious supplies of foods and products, environmentally unfriendly production processes and environmental disasters, increasing numbers of individuals are aware of environmental issues and feel our natural resources are limited and the environment is more fragile than we once believed. Such environmental awareness instils in the public a positive attitude toward eco-friendly activities and encourages people to more frequently engage in ecological behaviours in their everyday lives (Han and Hsu, 2011).

There are many studies in the context of Indian consumers exploring the consumer attitude and behaviour towards green practices, green buying behaviour and opportunity and challenges in green consumerism (Manaktola and Jauhari, 2007; Jain and Kaur, 2004; Kumar et al., 2010; Datta, 2011). Many studies show that the attitude-behaviour relationship has been strengthened when attitudes towards performing specific environmentally friendly behaviour (e.g., recycling), rather than towards general environmental issues. In general, empirical studies have implied a substantial positive relationship between ecological intention and behaviour (Chan, 2001). The bigger the positive attitudes, the more likely the intention to buy will be and therefore, the greater the likelihood that consumer will purchase green products over conventional alternatives. These studies have looked upon a range of issues in green consumerism and environmental aspect of marketing providing some good knowledge about Indian consumers but there is a gap in the literature when it boils down to finding a predictive relationship between different aspects during the process of adoption and purchasing of green products right from the formation of attitude to PI finally leading to PB in a complete cycle.

\subsection{Environmental concern}

Fundamental to environmental research is an individual's concern for the environment. Based on the pioneering research of Dunlap et al. (2000) EC is defined as a global attitude with indirect effects on behaviour through behavioural intention. Some other researchers mentioned that $\mathrm{EC}$ is a strong attitude towards preserving the environment (Kaufmann et al., 2012). 
Grunert and Juhl (1995) define an environmentally concerned consumer as one "who knows that the production, distribution, use and disposal of products lead to external costs and who evaluates such external costs negatively, trying to minimise them by her/his own behaviour". EC is often cited as a strong motivator for purchase. Huang (1996) recommends that the increased consumption of organic produce is related to an increased concern for environmental issues within society. This is supported by Tregear who found that purchasers of green products were more likely to engage in environmentally friendly activities like recycling in order to demonstrate their EC (Smith and Paladino, 2010). In general, evidence from different sectors shows that people's purchasing behaviour and attitude towards it is influenced by ECs (Mayer et al., 2012).

Heightened EC has been reflected in increased intention to purchase green products. More specifically it has been suggested that consumers with a higher level of EC will be more likely to engage in green consumer behaviour (Antil, 1984; Roberts, 1991; Sheltzer, 1991; Shabecoff, 1993). These claims have been supported by a number of surveys carried out recently which reported a dramatic increase in the number of consumers expressing ECs and claiming to have purchased green products.

Among psychographic measures, EC was one of the first variables to have been consistently reported as impacting on some forms of attitude towards green PB (Ellen et al., 1991) and its role was further confirmed in several studies (Ellen, 1994; Kim and Choi, 2005; Mostafa, 2007b; Roberts and Bacon, 1997; Straughan and Roberts, 1999), albeit with different degrees of intensity, depending on other variables included in the explaining models.

H1 EC has a positive effect on consumer's attitudes towards green products.

\subsection{Green advertising}

According to many researches being done in the past green advertising has emerged out to be an important factor affecting the attitude of consumers towards PI of green products. "Green advertising is an advertising that claims the advertised products or services are environmental friendly or that their production process conserves resources and energy" (Chang, 2011). GA can be varied in addressing issues from the "environmental issues, environmental friendliness of the products, corporate image campaigns and emphasis on the environmental credential of large companies, to public campaigns promoting environmental responsible behaviours" (Hartmann and ApaolazaIbanez, 2009). Advertising of the green products as safe for the environment influences the consumer's attitude to purchase the products, for instance, "more than half of the Americans say that they have purchased a product because the advertising or label indicated that it was environmental safe or biodegradable (Ginsberg and Bloom, 2004). Advertising cannot influence the consumer's attitude without highlighting the attribute of the green product.

However, another survey made on Malaysian consumers demonstrated that there is no relationship between environmental advertisements and PI of green products (Rahbar and Abdul Wahid, 2011). Indeed consumers pay attention to green advertisement and that permit them to obtain more information about eco-friendly products but it does not lead to purchase behaviour. However this survey only considered 250 Penang's consumers (Malaysia) so findings are not really generalised to consumers from industrialised countries. 
'Green advertising' must meet one or more of the following criteria:

- $\quad$ explicitly or implicitly addresses the relationship between a product or service and the biophysical environment

- promotes a green lifestyle with or without highlighting a product or service

- $\quad$ presents a corporate image of environmental responsibility (Gomon, 2005).

Audience behaviour towards the advertising can be indicated through consumers' favourable or unfavourable response towards a particular advertisement. According to Mehta, consumers' attitude towards advertising is one of the influential indicators of advertising effectiveness because consumer's cognitive ability towards the advertising are reflected in their thoughts and feelings and subsequently will influence their attitude towards advertising (Ling et al., 2010).

H2 GA has a positive effect on consumer's attitudes towards green products.

\subsection{Perceived quality of green products}

Product attributes such as convenience, availability and quality play an important role in the consumers' purchasing decision process (Gan et al., 2008). A consumer's choice for or against organic products can be framed as a social dilemma, in which he or she must weigh individual motives, such as quality considerations. The perceived level of quality, which is an overall evaluative judgment of a product's items and a key dimension in product choice and attitude towards PI of that product (Van Doorn and Verhoef, 2011).

The product quality can be a good starting point for providing customer satisfaction and producing customer loyalty. Ettlie and Johnson (1994) explained that product quality as the result of performance, which, in turn can be labelled as the degree of customisation and freedom from defects or how reliably the product met customer requirements. The product quality dimension included product packaging, product design, product features, warranties, etc. Many companies can not only embody green or environmental concept in the feature, design and package of their product to increase product differentiation, but they should also satisfy the environmental requirements of customers and further create customer loyalty as well as a competitive advantage (Chang and Fong, 2010).

H3 Quality has a positive effect on consumer's attitudes towards green products.

\subsection{PI and attitude}

Intention is the likelihood that a person will engage in a specific behaviour. Intention is the best predictor of behaviour and hence, to change a specific behaviour, one must first change the intention to perform that behaviour. $\mathrm{Ng}$ and Paladino (2009) described behavioural intentions as a measure of a person's relative strength of cause to execute certain conduct. Rashid (2009) described green PI as the opportunity and willingness of a person to provide desire to green product over traditional products in their purchasing concerns. Whereas, Ramayah et al. (2010) stated that green PI is dedication to behave in a positive manner.

Attitude has been described as an intellectual and neural state of readiness. This kingdom of thoughts essentially impacts the response of the target market in the direction 
of all objects and conditions with which the target audience is faced. One extension of this phenomenon has been aptly undertaken by means of Schultz and Zelezny (2000), who define it with the aid of contemplating the mindset closer to ECs. They describe it as the deep rooted concept in a person's self with a belief of the diploma of bonding between self and the surroundings. Irland (1993) mentions that a purchaser's purchasing intentions are dependent upon his or her environmental attitudes. A beneficial mindset towards a product which is environmental friendly ads to sustainable consumption behaviour as talked about in numerous research (Chan, 2001; Tanner and Kast, 2003; Vermeir and Verbeke, 2004). The mind-set acts as a vital antecedent to the behavioural intention that is defined as the degree of favourable or unfavourable evaluation of the behaviour underneath a study (Ajzen, 1991). Cheng et al. (2006) concluded that a person willing to show a specific behaviour may additionally adopt the cost benefit analysis due to the movement undertaken and favourable mindset is connected with advantageous evaluation of the action (Ajzen, 1991; Cheng et al., 2006). Ajzen (1991) emphasised that positive mindset toward a particular behaviour strengthens the intention to carry out that behaviour. Under this discussion, it is far hypothesised that:

H4 An attitude towards green products has positive relationship with the PI for the products.

\subsection{Subjective norm and PI}

Fishbein and Ajzen (1975) declared that subjective norm is the perceived social pressure that encourages one to engage in a specific behaviour. Subjective norm is a prevalent behavioural standard followed by a social group (Coleman, 1990). That is, subjective norm is the measure of pressure exerted by the social group which the individual takes into account before making a behavioural decision (Venkatesh and Davis, 2000). Fishbein and Ajzen (1975) proposed that pressure and the social group are the constructs of subjective norm. Ajzen (1991) further pointed out that social influence (SI) and motivation to comply (MTC) are the functions of subjective social norm. When predicting the behaviour of an individual, the specific behaviour will be related to the reference group.

SI which the information provided by people can have a big impact on consumers. To further explain SI definition, Kalafatis et al. (1999) explained social norm is whether an action should or should not be performed by a respondent in a referent's point of view. For instances, the referents could be friends, neighbours not for profit or for profit organisations, teachers, parents and etc.

Ajzen's TPB explains the factor of Subjective norms which are associated with social pressures to perform or not to perform a specific behaviour (Han et al., 2010). Han et al. (2010) also highlight the issue of referents where a consumer would act thinking whether their referent would approve or disapprove certain behaviour. SIs have said to promote many recycling activities in young consumers specially (Pickett-Baker and Ozaki, 2008). Young consumers are strongly affected by the coercive power of the group they belong to and are open to change more easily (Pickett-Baker and Ozaki, 2008).

Another factor affecting the subjective norm of consumers towards green marketing is word of mouth (WOM). The WOM is 'the informal transmission of ideas, comments, opinions and information between two people, neither one of which is a marketer'. Two subjects are involved in WOM one who "gains information about behaviours and 
choices": the receiver and the second who "increases his/her confidence in the personal product or behaviour choice by persuading others to do the same" (Blackwell et al., 2006). Green products are not exception of the WOM promotion to target consumers and influence their attitudes for the purchases of the green products.

Subjective norm has been extensively analysed in the studies on environmentally responsible behaviour (Biel and Thøgersen, 2007). Various studies such as the study on sustainable food by Vermeir and Verbeke (2006), study on organic food by Chen (2007) and Gotschi et al. (2007) indicate a relationship between subjective norm and a consumer's intention to engage in that behaviour which is both significant and positive. Some other studies undertaken by scholars such as Sidique et al. (2010) and Pearson et al. (2008) conclude that exhibition of behaviour resulting in betterment of environment such as recycling was directly affected by the extent of the social pressure or social norm and the directionality of such relationship was positive in nature. Based on these discussions, it is hypothesised that:

H5 Subjective norm has a positive effect on PI of green products.

\subsection{Subjective norm and attitude}

The TPB has been applied in many studies involving organic food buying behaviour (Sparks and Shepherd, 1992) and in examining the intentions to purchase green products (Kalafatis et al., 1999). However, in the previous studies on green products buying behaviour, the role of subjective norms which refers to the perceived social pressure to perform or not to perform the behaviour (Ajzen, 1991) has repeatedly been neglected. For instance, Magnusson (2001) did not consider them for their model on green buying behaviour at all. Sparks and Shepherd (1992) included subjective norms in their study but its explanatory power was relatively weak, even though it was significant. Chang (1998) and Shepherd and O'Keefe (1984) have found evidence that there is a significant causal path from subjective norm to attitude which were neglected in prior studies. Chang (1998) has noted the relationship between subjective norm and attitude and suggests that if this relationship exists, then the effect of the significant other on attitude formation cannot be ignored. Chang (1998) investigated the correlations between subjective norms and attitudes towards behaviour more thoroughly and tested the causal link from norms to attitudes. In his study, the relationship between them was found to be significant. He suggested that the link could be explained with social environment's influence on an individual's attitude formation. On basis of this study we make the hypothesis that:

H6 Subjective norm positively affects the attitude towards green products.

\subsection{Green purchase behaviour and PI}

Behaviour can be determined from the intention with big accuracy (Ajzen, 1991). Many studies have showed the connection between intention and real behaviour (Fishbein and Ajzen, 1980; Sheppard et al., 1988). Historically, Intention has been assumed to be robust predictor of behaviour but in a few instances it can no longer act in constant manner. In a study on the behaviour bearing on the usage of information technology, Venkatesh et al. (2003) suggested a small to medium impact size of intention to use information technology on the actual behaviour. This may be attributed to as intention - behaviour 
gap and the equal has been showed in study by Grunert and Juhl (1995) also who concluded that intention may not always cause the favourable behaviour. However, numerous researchers consisting of Sheppard et al. (1988) mentioned an excessive degree of correlation between intention and behaviour. Researchers analysing the buying behaviour for natural food have determined significantly positive relationship between PI and purchase behaviour (Saba and Messina, 2003; Thøgersen and Zhou, 2012). In view of the discussion, it is hypothesised that:

H7 PI is positively related to the purchase behaviour for green products.

The present study attempts to fill the research gap by incorporating the TPB (Ajzen, 1991) to understand the behaviour of the consumers towards purchasing of green products in the context of Indian consumers using structural equation modelling (SEM). The study looks at the relationship of PI with variables like attitude which is construct dependent on factors namely, EC, green attitude and perceived quality of the products finally leading to purchase behaviour.

Hence, the main contribution of this study is to find out the relationship between attitude towards green products and PI by incorporating other determinants also which affect the PI and eventually purchase behaviour in a complete framework in the context of Indian consumers.

\section{Conceptual framework}

With reference to the foregoing literature review, a conceptual model is proposed in Figure 2 to explain Indian consumers' green purchase behaviour.

Figure 2 Conceptual model (see online version for colours)

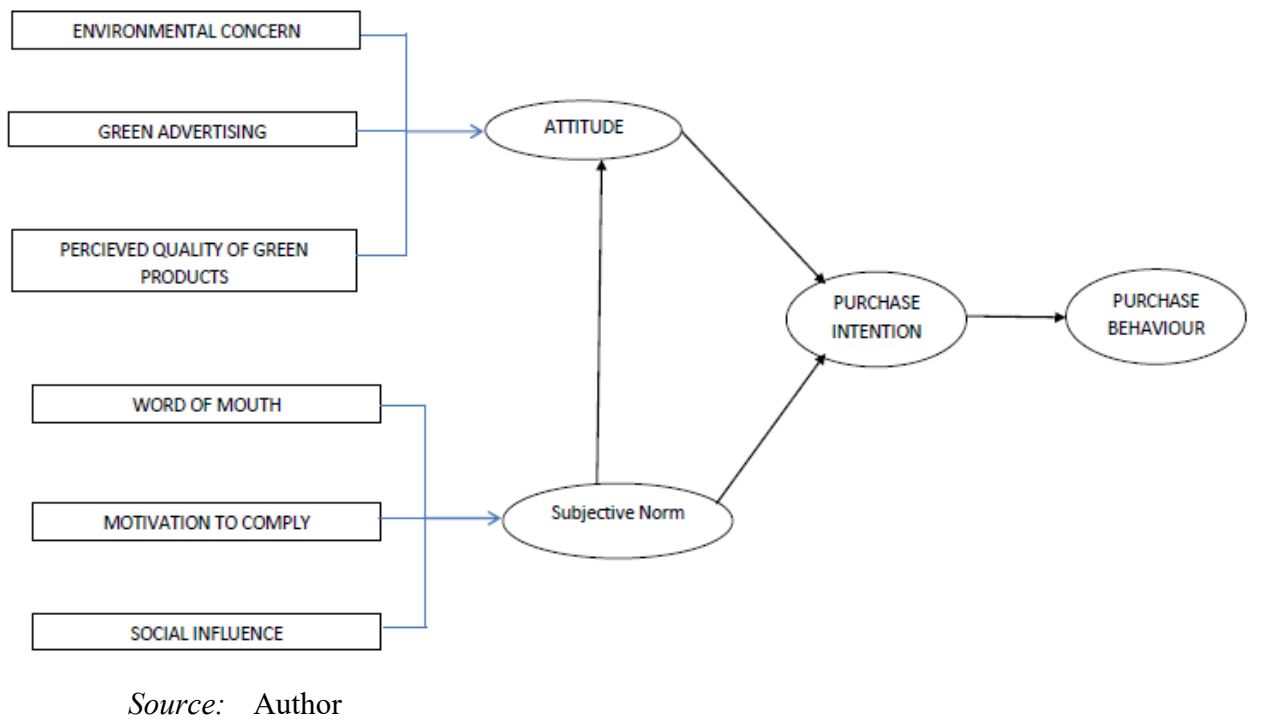




\section{Research objectives}

SEM is a family of statistical methods which encompasses confirmatory factor analysis (CFA), correlated uniqueness models, latent growth models, multiple indicators and multiple causes' models and item-response theory models. It is used to test a theoretical model in which inter correlations and hypotheses that a relationship between observed variables and their underlying latent constructs exists are tested. CFA is a powerful statistical technique which is used to measure the consistency of a construct. In this study, CFA is used to check whether the hypothesised measurement model can be fitted to the data or not. The objectives of the research are:

1 to examine the determinants of consumer attitude towards green products

2 to investigate the relationship between subjective norms and attitude towards green products

3 to ascertain the relationship between consumer attitude, subjective norm and PI leading to purchase behaviour of the green products.

\section{Research methodology}

Data were collected from the respondents from New Delhi with varied age groups and different annual incomes. A self administered questionnaire was given to respondents to collect the data. All items were borrowed from the existing literature of different countries with a slight modification to fit the specific context of green purchasing behaviour in India. The questionnaire contained nine-point Likert scale items for which the respondents were required to provide their responses with values ranging from 'strongly disagree: 1' to 'strongly agree: 9'. The respondents were also required to provide the information related to their demographic profiles for the purpose of classification.

The final version of the questionnaire was an adapted version of the scale mentioned in marketing scales handbook: A Compilation of Multi-Item Measures for Consumer Behaviour and Advertising Research, (Kilbourne and Pickett, 2008; Straughan and Roberts, 1999; Baker and Churchill, 1977; Lee, 2008). Some modifications in terms of content as well as the number of questions were done to adapt the same for consumer markets in Indian context. This paper works towards the assessment of factors that lead to attitude and subjective Norms towards PI of green products while analysing the relationship between attitude and subjective norms which ultimately leads to green purchase behaviour.

A pilot study was done on the 37 -items measurement instrument to examine the initial reliability of the instrument. Sample size for this test was kept very small (70) as this was an initial test. The modified self-administrated questionnaires consisting of 37 statements for eight sub-scales was formulated that measured GA, EC, PQGP, WOM, MTC, SI, PI and green purchase behaviour were distributed in the printed form as well as online to the respondents. 
A total of 501 pieces of usable questionnaire out of total sample size of 570 was collected on which Cronbach's alpha test was used to test the reliability of the data that came out to be 0.904 (Table 1).

Table 1 Reliability statistics

\begin{tabular}{lc}
\hline Variable & Cronbach's alpha \\
\hline Environmental concern & 0.923 \\
Green advertising & 0.901 \\
Perceived quality of green products & 0.925 \\
Word of mouth & 0.861 \\
Motivation to comply & 0.881 \\
Social influence & 0.859 \\
Purchase intention & 0.853 \\
Purchase behaviour & 0.827 \\
\hline
\end{tabular}

Source: SPSS output file

\section{Analysis of the data}

The questionnaire was personally administered and monitored while collecting the data so that no field is left unanswered. Due precautions were taken while designing the same to have specific scale with options. This eliminated the discrepancies arising out of missing frequencies and outliers from the data. This further helped in getting rid of any coding errors in the data.

Most commonly used computerised statistical tools, SPSS version 20.0 and AMOS, were used for the analysis of data while the hypothesis was tested using CFA and descriptive analysis (DA). The analysis was performed at $95 \%$ confidence level which is generally accepted level of confidence in social sciences research. The data thus collected was transformed into tabular form that is the most suitable form to present the data analysis and the same was entered in SPSS 20.0 for analysis.

\subsection{Profile of respondents}

Out of 501 questionnaires collected 51\% were males (256) and 49\% were females (245) with $21.4 \%$ of the respondents in the age bracket of $18-25$ years (107), $28.9 \%$ in $26-35$ years, $25.3 \%$ in $36-45$ years and $24.4 \%$ in above 46 years. $54.3 \%$ (272) of the respondents were married and $45.7 \%$ (229) of the total respondents were unmarried. $29 \%$ of the respondents were service class and almost equal percentages of respondents were students $(25.5 \%)$ and were in business $(21.4 \%)$. Majority of the respondents belonged to the income group of less than 2.5 lakhs $(35.1 \%)$ with the least number of respondents in the income bracket of above 8 lakhs $(20.6 \%) .35 .5 \%$ of the respondents purchase eco-friendly products once a week or more often and a comparable $36.5 \%$ of the respondents purchase online eco-friendly products at least once a month, whereas $27.9 \%$ of the respondents purchase eco-friendly products less than once a month. 


\subsection{Confirmatory factor analysis}

On the basis of theory or literature review, CFA is used to examine the hypothesised relationships between constructs and attitude as well as subjective norm which are the latent variables further leading to PI and green purchase behaviour. As per the nature of the latent variables or constructs, key model constructs are shown in the Table 2.

Table 2 Constructs

\begin{tabular}{|c|c|}
\hline \multirow{7}{*}{$\begin{array}{l}\text { Environmental } \\
\text { concern }(\mathrm{EC})\end{array}$} & I am worried about the worsening of the quality of India's environment. \\
\hline & I would be willing to reduce my consumption to help protect the environment. \\
\hline & $\begin{array}{l}\text { To maintain a healthy economy, we will have to develop a steady-state } \\
\text { economy where industrial growth is controlled. }\end{array}$ \\
\hline & $\begin{array}{l}\text { Humans need to adapt to the natural environment because they cannot remake } \\
\text { it to suit their needs. }\end{array}$ \\
\hline & Major social changes are necessary to protect the natural environment. \\
\hline & India's environment is my major concern. \\
\hline & I often think about how the environmental quality in India can be improved. \\
\hline \multirow{4}{*}{$\begin{array}{l}\text { Green } \\
\text { advertising } \\
\text { (GA) }\end{array}$} & The brands of green products stand for its promises. \\
\hline & $\begin{array}{l}\text { In general, statements shown in advertisements about green product are } \\
\text { believable. }\end{array}$ \\
\hline & $\begin{array}{l}\text { Over time, experiences with the green brand have made me think the brand } \\
\text { meets its promises, without exceeding my expectations but without falling } \\
\text { below them. }\end{array}$ \\
\hline & I can trust in the green brand's name of its advertising. \\
\hline \multirow{4}{*}{$\begin{array}{l}\text { Perceived } \\
\text { quality of } \\
\text { green products } \\
\text { (PQGP) }\end{array}$} & $\begin{array}{l}\text { The green products meet or exceed the requirements of environmental } \\
\text { regulations. }\end{array}$ \\
\hline & The green products consume the least amount of resources and energy. \\
\hline & The green products are easy to recycle, disassemble, decompose, and reuse. \\
\hline & The quality of the green products is superior. \\
\hline \multirow{4}{*}{$\begin{array}{l}\text { Word of } \\
\text { mouth } \\
\text { (WOM) }\end{array}$} & $\begin{array}{l}\text { You would highly recommend any product to others because of its } \\
\text { environmental image }\end{array}$ \\
\hline & $\begin{array}{l}\text { You would say positive things about a product to others because of its } \\
\text { environmental functionality. }\end{array}$ \\
\hline & $\begin{array}{l}\text { You would encourage others to purchase any product because it is } \\
\text { environmental friendly/green }\end{array}$ \\
\hline & $\begin{array}{l}\text { You would introduce any product to others because of its environmental } \\
\text { performance. }\end{array}$ \\
\hline \multirow{4}{*}{$\begin{array}{l}\text { Motivation to } \\
\text { comply } \\
\text { (MTC) }\end{array}$} & $\begin{array}{l}\text { When it comes to purchasing green products, I want to do what my family } \\
\text { wants me to do. }\end{array}$ \\
\hline & My family's approval of my purchasing green products is important to me. \\
\hline & $\begin{array}{l}\text { Most people who are important to me think that I should purchase green } \\
\text { products in the next } 12 \text { months }\end{array}$ \\
\hline & $\begin{array}{l}\text { The people in my life whose opinions I value would Strongly approve of my } \\
\text { purchasing green products in the next } 12 \text { months }\end{array}$ \\
\hline
\end{tabular}


Table 2 Constructs (continued)

\begin{tabular}{ll}
\hline Social & People who are important to me and influence my behaviour would encourage \\
influence (SI) & me to buy green products. \\
& My family thinks that I should purchase green products. \\
& My friends think that I should purchase green products. \\
& I have read/seen news reports which say that purchasing green products \\
contributes to a good environment. \\
Mass media reports have influenced me to try green products. \\
I would like to use green products. \\
purchase \\
intention (PI) \\
I would buy green products if I happen to see them in a store. \\
I would actively seek out green products in a store in order to purchase it. \\
I would patronise and recommend the use of green products. \\
If I understand the potential damage to the environment that some products \\
can cause, I do not intend to purchase those products. \\
I prefer green products over non-green products when their product qualities \\
purchase \\
behaviour
\end{tabular}

Source: Author

The present study used AMOS statistical software to conduct CFA to test the efficiency of the 8 constructs. According to Holtzman and Leich (2014), when running CFA, there are various fit statistics which help to examine the model fitness for the data as shown in Table 3.

The ratio of goodness of fit to degrees of freedom should be no more than 3 (Carmines and MacIver, 1981) and the value of RMSEA should be less than 0.08, with the GFI, IFI, NFI, CFI exceeding 0.9 (Bagozzi and Yi, 1988). Furthermore, RMR which stands for root mean residual is associated to the residual in the attitude model. The range of RMR value is zero to one where a smaller RMR shows better model fit.

Table 3 Model fit Indices for 1st order CFA

\begin{tabular}{lcccccc}
\hline & CMIN/DF & GFI & CFI & IFI & NFI & RMSEA \\
\hline Desired value & 3 or lower & $\begin{array}{c}0.90 \text { or } \\
\text { higher }\end{array}$ & $\begin{array}{c}0.90 \text { or } \\
\text { higher }\end{array}$ & $\begin{array}{c}0.90 \text { or } \\
\text { higher }\end{array}$ & $\begin{array}{c}0.90 \text { or } \\
\text { higher }\end{array}$ & $\begin{array}{c}0.08 \text { or } \\
\text { lower }\end{array}$ \\
Values from the model & 1.567 & 0.908 & 0.968 & 0.968 & 0.917 & 0.034 \\
\hline
\end{tabular}

Source: AMOS output file

Table 3 shows that model is fitted to the data as GFI, CFI, NFI and IFI are greater or equal to 0.90 which is considered acceptable. Moreover, value of RMSEA is equal or less than 0.08 and value of CMIN/DF should be less than 3 which are considered acceptable. 
Figure 3 CFA model (see online version for colours)

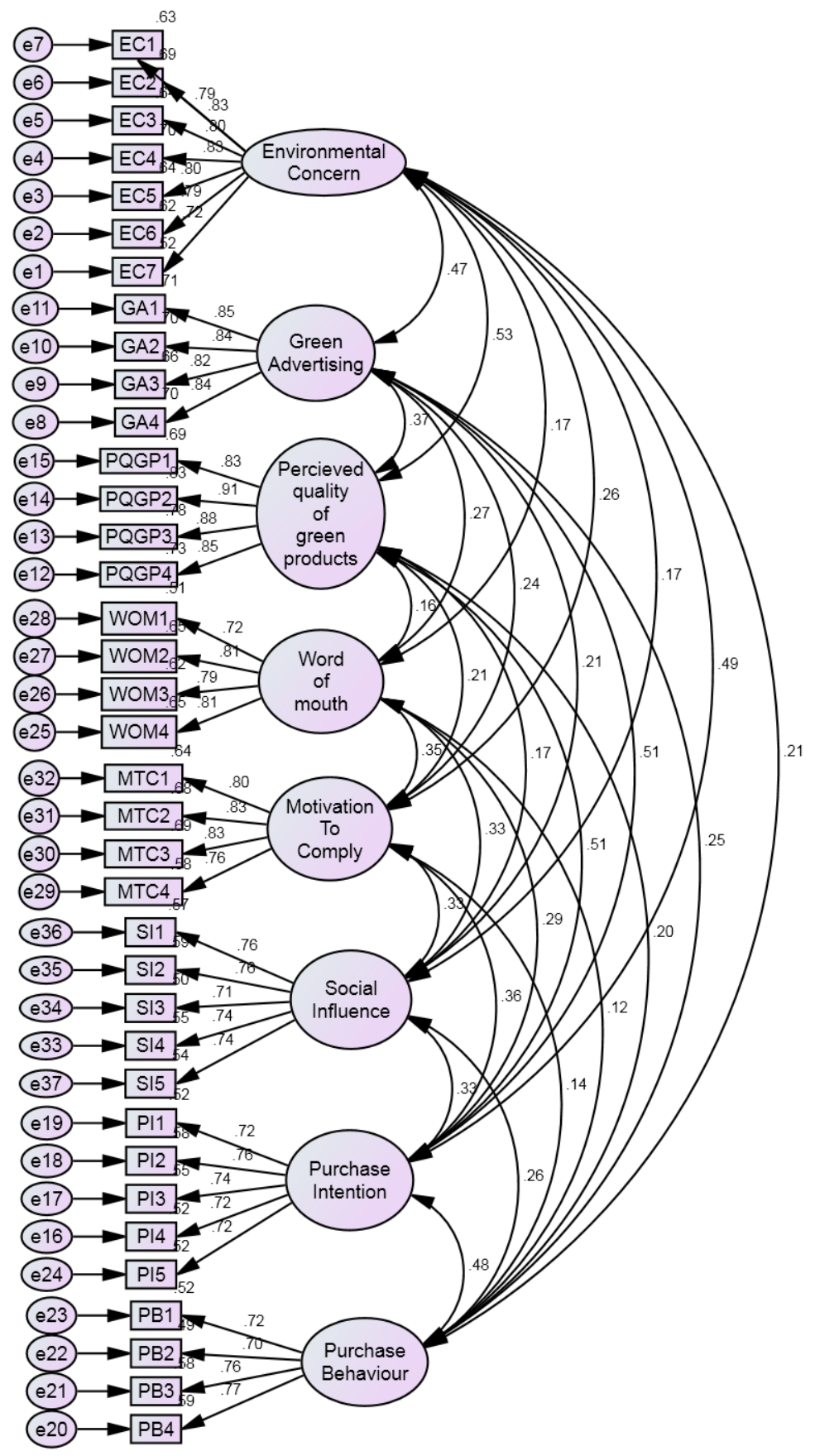

Source: Output of AMOS 
The model for first order CFA is shown in Figure 3.

\subsection{Validity assessment}

- Convergent validity assessment: $(\mathrm{CR}>0.7$; AVE $<\mathrm{CR}$; $0.5<\mathrm{AVE})$

- Validity of discriminant: (AVE $>$ MSV, ASV < AVE)

As per Table 4, CR is more than 0.7 and AVE is more than 0.5 for all the five factors. Also, the Table 4 shows that CR is higher than AVE for all factors. So, we can conclude that the factors in the measurement model have sufficient convergent validity. As per the measurement model, MSV is less than AVE for all the factors. Also, ASV is less than AVE for all the factors. Hence, we can confirm discriminant validity of the measurement model.

Table 4 Convergent and discriminant validity of the CFA model

\begin{tabular}{lcccccccccccc}
\hline & $C R$ & $A V E$ & $M S V$ & $\operatorname{MaxR}(H)$ & $M T C$ & $E C$ & $G A$ & $P Q G P$ & $P I$ & $P B$ & WOM & $S I$ \\
\hline MTC & 0.882 & 0.651 & 0.128 & 0.884 & 0.807 & & & & & & & \\
EC & 0.923 & 0.632 & 0.281 & 0.952 & 0.260 & 0.795 & & & & & & \\
GA & 0.901 & 0.694 & 0.257 & 0.967 & 0.242 & 0.474 & 0.833 & & & & & \\
PQGP & 0.926 & 0.757 & 0.281 & 0.977 & 0.208 & 0.530 & 0.370 & 0.870 & & & & \\
PI & 0.853 & 0.536 & 0.261 & 0.980 & 0.358 & 0.489 & 0.507 & 0.511 & 0.732 & & & \\
PB & 0.827 & 0.545 & 0.234 & 0.982 & 0.144 & 0.208 & 0.249 & 0.195 & 0.484 & 0.739 & & \\
WOM & 0.862 & 0.611 & 0.119 & 0.984 & 0.345 & 0.174 & 0.270 & 0.162 & 0.291 & 0.117 & 0.781 & \\
SI & 0.859 & 0.550 & 0.111 & 0.985 & 0.332 & 0.171 & 0.210 & 0.169 & 0.333 & 0.264 & 0.330 & 0.742 \\
\hline
\end{tabular}

Source: AMOS output file

Table 4 shows that there is convergent and discriminant validity in the factors of the measurement model as the value of all constructs are acceptable. After conducting CFA it was found that model fitted successfully in Indian scenario.

\subsection{Structural model analysis}

The present study conducted a linear analysis of the structural relation model using AMOS statistical software to understand causality and correlation among the variables.

According to Holtzman and Leich (2014), SEM is used to examine how well the assessment predicts these measures. Also, the same fit statistics, which we discussed for the CFA should be considered when running SEM (Figure 4).

The results show that the value of $\chi 2 / \mathrm{df}$ is 1.570 , the value of RMR is 0.203 , the value of GFI is 0.905 , the value of AGFI is 0.892 , the value of NFI is 0.914 , the value of RFI is 0.908 , the value of CFI is 0.967 and the value of RMSEA is 0.034 . The fit of the model is therefore acceptable. In addition, the analysis showed that all the hypotheses were supported. The complete results are presented in Figure 4. 
Figure 4 Results of SEM analysis (see online version for colours)

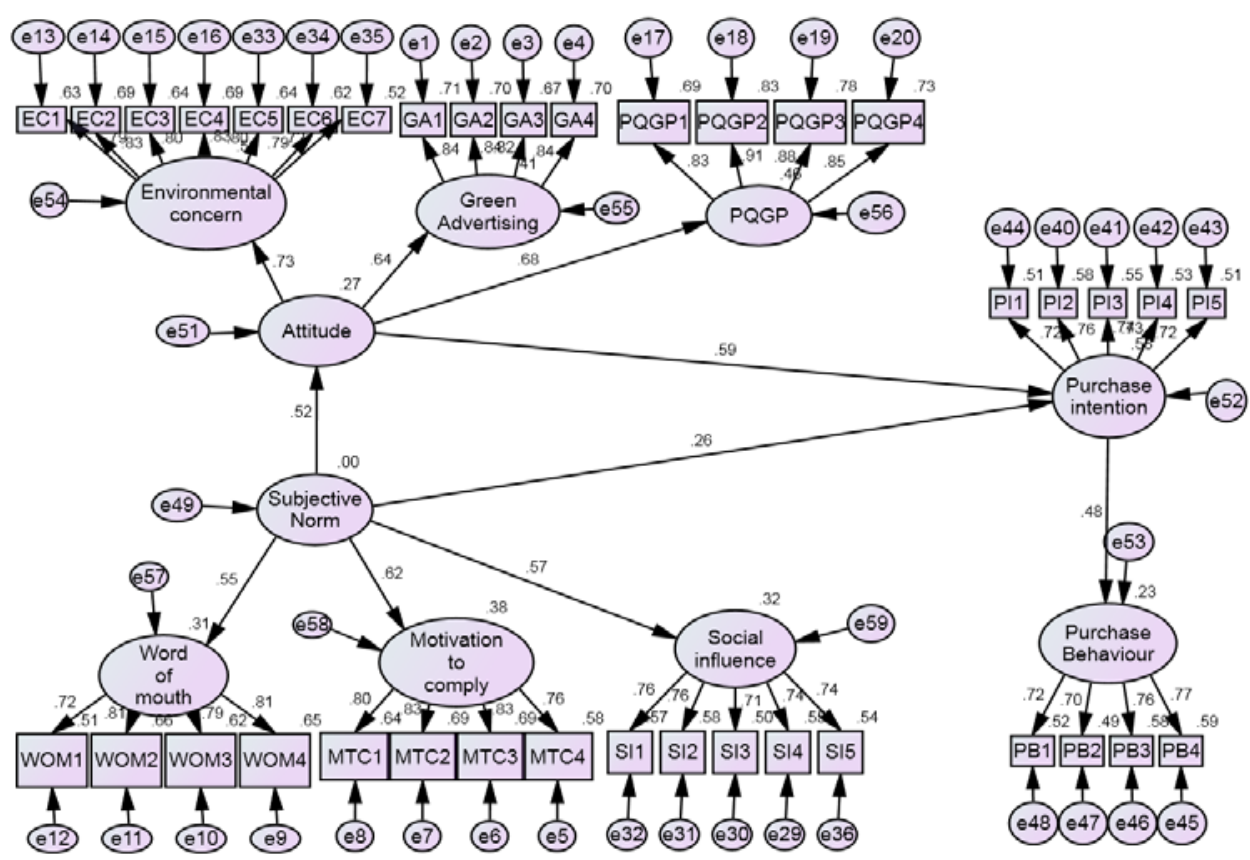

Source: SPSS output file

\subsection{Hypothesis testing and inductive analysis}

The empirical results in Table 5 show that:

1 EC is significantly positively related to attitude

2 GA is significantly positively related to attitude

3 PQGP and attitude are significantly positively related

4 attitude is significantly positively related to PI of green products

5 PIs are significantly positively related to actual purchase behaviour.

$\mathrm{H} 4$ and $\mathrm{H} 7$ were supported at the $1 \%$ significance level, these suggest that intentions of green purchasing do influence green purchasing behaviour and attitudes do influence purchases intentions. These findings are also consistent with other research conducted (Smith and Paladino, 2010). The results obtained for the some antecedents will now be investigated. The first variable examined was EC, which is concerned with H1. H1, which specifies the relationship between EC and attitude, was supported at the $1 \%$ level. This is consistent with past research that has found the consumers purchase green products for EC (Smith and Paladino, 2010). 
Table 5 Summary of the structural model

\begin{tabular}{lcccc}
\hline \multicolumn{5}{c}{ Summary of the structural model } \\
\hline Path description & Hypothesis & $\begin{array}{c}\text { Unstandardized } \\
\text { path estimates }\end{array}$ & $\begin{array}{c}\text { Standardized } \\
\text { path estimates }\end{array}$ & Result \\
\hline Environmental concern $\rightarrow$ Attitude & $\mathrm{H} 1$ & $1.000^{* * *}$ & 0.727 & Supported \\
$\begin{array}{l}\text { Green advertising } \rightarrow \text { Attitude } \\
\text { Perceived quality of green products }\end{array}$ & $\mathrm{H} 2$ & $0.961^{* * *}$ & 0.642 & Supported \\
$\rightarrow$ Attitude & $\mathrm{H} 3$ & $0.975^{* * *}$ & 0.676 & Supported \\
$\begin{array}{l}\text { Attitude } \rightarrow \text { Purchase intention } \\
\begin{array}{l}\text { Subjective norm } \rightarrow \text { Purchase } \\
\text { intention }\end{array}\end{array} \mathrm{H}^{\text {Subjective norm } \rightarrow \text { Attitude }}$ & $\mathrm{H} 5$ & $0.791^{* * *}$ & 0.590 & Supported \\
$\begin{array}{l}\text { Purchase intention } \rightarrow \text { Purchase } \\
\text { behaviour }\end{array}$ & $\mathrm{H} 6$ & $0.648^{* * * *}$ & 0.262 & Supported \\
\hline
\end{tabular}

Source: Author by using AMOS output file

The impact of quality on attitude (H2) was supported at $1 \%$ level and consistent with past research (Chang and Fong, 2010). H3 was supported at the 1\% significant level. This hypothesis suggests that GA has a positive effect on consumer's attitudes. Also, subjective norms positively influence the PIs as $\mathrm{H} 5$ was supported at $1 \%$ significance level. Our analysis also indicates a positive relation between subjective norms and attitude towards green products as $\mathrm{H} 6$ is supported at 1\% significance level. Although the effect of subjective norm is comparatively less than attitude on PI of the green products, but it cannot be undermined as the result is significant.

\section{Conclusions}

The TPB proved its applicability in explaining social behaviour aimed at green products purchases. The TPB model was tested on a large representative sample of consumers from New Delhi and NCR region in India and its predictive ability corresponds with other examples. The best predictors of the intention to purchase green products are attitudes towards the behaviour. This study shows that the intention of consumers to purchase green products is determined by having a positive attitude toward green products. This finding is also consistent with the results obtained on similar relationship in the study by Chan and Lau (2002) and Ramayah et al. (2012). The present study also has examined the influence of various personal and marketing factors on the attitude toward green products of consumers from Delhi. The results from the structural-equation modelling show the EC has the highest influence on attitude towards green products among three personal variables including EC, GA and PQGP. The study also explored the relationship between subjective norm and attitude towards green products.

The subjective norm which is referred to as perceived social demand to execute a particular behaviour was found to be significant and comparatively low in terms of its estimated value in this study. Many researchers such as Trafimow and Finlay (1996) and Cialdini and Trost (1998) have also discussed the relatively weaker impact of subjective norm in TPB. These scholars mentioned that the subjective norm was more relevant to 
the individuals who could access the collective self in a prominent manner. The results of this research have implications for the marketing of these products to consumers and for researchers. Marketers of green products should link these products with concern for environmental issues within society to promote these products.

\section{Managerial implications}

The findings of this study have provided valued knowledge on the prerequisite of the PI which finally leads to purchase behaviour for green products in Indian context. These findings can help the marketers to formulate their policy with regard to actions which would enhance the purchase and usage behaviour of the consumers towards green products. It is important for the policy makers working towards improvement of environment to understand the behavioural aspects of the consumption so that they could make people change and believe in certain aspect of their action leading to betterment of the environment and ecology. Marketers need to keep in mind that EC, GA and quality of the green products have significant and positive impact on the attitude towards green products.

The current study would help them in understanding an important element of the marketing strategy which is the behaviour of consumers. The findings such as significant impact of subjective norm on PI could be a new thing for a collectivistic culture like India; hence marketers may have to collaborate the traditional way of managing marketing activities targeted on collectivistic nature of Indian culture. As there is an important relationship between attitude and subjective norm, the mediating role of attitude can be studied in between subjective norm and PI of the green products.

It provides them with the opportunity to design their communication content in line with requirements to enhance the knowledge level of target audience. There is always a concern towards authenticity of the claims made by marketers for the green products. The apprehension is more enhanced in the absence of appropriate communication that tells about the genuineness of the claim. A right set of knowledge spread through genuine advertisement is expected to have positive impact on the attitude of the consumers as per the findings of this study.

\section{Limitations and directions for future research}

The empirical outcomes acquired in this study are consistent with the theoretical history and also with the general belief on the subject matter. Despite this, the present study has few limitations. The study was undertaken in a single Indian city, i.e., in a specific geography subsequently the study might not have blanketed all of the relevant ecological diversities at a more aggregate degree. This unpredictability may rely upon many elements inclusive of price, availability, degree of involvement, etc. (Vermeir and Verbeke, 2004). These aspects can be investigated in future studies.

The present study has been conducted via considering only one construct of the TPB which is attitude and its antecedents. Future research wants to investigate the position of different important constructs which can be subjective norms and PBC. They may additionally involve many important elements such as SI, WOM, MTC, perceived 
consumer effectiveness and control on availability of green products which might act as moderator or mediator with the various constructs of the model. Since environmental issue is a vital coverage trouble on worldwide degree, it is prudent to look at the position of environmental rules as a moderator to the $\mathrm{PB}$ in the model. Also, group moderation can also be studied keeping as various demographic factors as moderators.

\section{References}

Ajzen, I. (1985) From Intentions to Actions: A Theory of Planned Behaviour, pp.11-39, in Action Control, Springer Berlin Heidelberg.

Ajzen, I. (1991) 'The theory of planned behavior', Organizational Behavior and Human Decision Processes, Vol. 50, No. 2, pp.179-211.

Ajzen, I. and Fishbein, M. (1975) Belief, Attitude, Intention and Behavior: An Introduction to Theory and Research, Vol. 6, Addison-Wesley, MA.

Ajzen, I. and Fishbein, M. (1980) Understanding Attitudes and Predicting Social Behavior.

Alsmadi, S. (2007) 'Green marketing and the concern over the environment: measuring environmental consciousness of Jordanian consumers', Journal of Promotion Management, Vol. 13, No. 34, pp.339-361.

Antil, J.H. (1984) 'Socially responsible consumers: profile and implications for public policy', Journal of Macro Marketing, Vol. 4, No. 2, pp.18-39.

Bagozzi, R.P. and Yi, Y. (1988) 'On the evaluation of structural equation models', Journal of the Academy of Marketing Science, Vol. 16, No. 1, pp.74-94.

Baker, M.J. and Churchill, Jr., G.A. (1977) 'The impact of physically attractive models on advertising evaluations', Journal of Marketing Research (pre-1986), Vol. 14, No. 000004, pp.538-555.

Biel, A. and Thøgersen, J. (2007) 'Activation of social norms in social dilemmas: a review of the evidence and reflections on the implications for environmental behaviour', Journal of Economic Psychology, Vol. 28, No. 1, pp.93-112.

Blackwell, R.D., Miniard, P. and Engel, J. (2006) Consumer Behaviour, International Student Edition, Thomson Higher Education, Mason, OH.

Carmines, E.G. and McIver, J.P. (1981) 'Analyzing models with unobserved variables: analysis of covariance structures', Social Measurement: Current Issues, Vol. 20, No. 4, pp.65-115.

Chan, R.Y.K. (2001) 'Determinants of Chinese consumers' green purchase behavior', Psychology and Marketing, Vol. 18, No. 4, pp.389-413.

Chan, R.Y.K. (2004) 'Consumer responses to environmental advertising in China', Marketing Intelligence and Planning, Vol. 22, No. 4, pp.427-437.

Chan, R.Y.K. and Lau, L.B.Y. (2002) 'Explaining green purchasing behavior', Journal of International Consumer Marketing, Vol. 14, Nos. 2-3, pp.9-40.

Chang, C. (2011) 'Feeling ambivalent about going green', Journal of Advertising, Vol. 40, No. 4, pp.19-32.

Chang, M.K. (1998) 'Predicting unethical behavior: a comparison of the theory of reasoned action and the theory of planned behavior', Journal of Business Ethics, Vol. 17, No. 16, pp.1825-1834.

Chang, N.J. and Fong, C.M. (2010) 'Green product quality, green corporate image, green customer satisfaction and green customer loyalty', African Journal of Business Management, Vol. 4, No. 13, p.2836.

Chen, M.F. (2007) 'Consumer attitudes and purchase intentions in relation to organic foods in Taiwan: moderating effects of food-related personality traits', Food Quality and Preference, Vol. 18, No. 7, pp.1008-1021. 
Cheng, S., Lam, T. and Hsu, C.H. (2006) 'Negative word-of-mouth communication intention: an application of the theory of planned behavior', Journal of Hospitality and Tourism Research, Vol. 30, No. 1, pp.95-116.

Cialdini, R.B. and Trost, M.R. (1998) 'Social influence: Social norms, conformity and compliance', in Gilbert, D.T., Fiske, S.T. and Lindzey, G. (Eds.): The Handbook of Social Psychology, pp.151-192, McGraw-Hill, Boston.

Coleman, J.S. (1988) 'Social capital in the creation of human capital', The American Journal of Sociology, Vol. 94, No. 1, pp.95-120.

Datta, S.K. (2011) 'Pro-environmental concern influencing green buying: a study on Indian consumers', International Journal of Business and Management, Vol. 6, No. 6, p.124.

Dunlap, R.E., Van Liere, K.D., Mertig, A.G. and Jones, R.E. (2000) 'New trends in measuring environmental attitudes: measuring endorsement of the new ecological paradigm: a revised NEP scale', Journal of Social Issues, Vol. 56, No. 3, pp.425-442.

Ellen, P.M. (1994) 'Do we know what we need to know? Objective and subjective knowledge effects on pro-ecological behaviors', Journal of Business Research, Vol. 30, No. 1, pp.43-52.

Ellen, P.S., Weiner, J.L., Cobb-Walgreen, C. (1991) 'The role of perceived consumer effectiveness in motivating environmentally conscious behaviors', Journal of Public Policy and Marketing, Vol. 10, No. 2, pp.102-117.

Ettlie, J.E. and Johnson, M.D. (1994) 'Product development benchmarking versus customer focus in applications of quality function deployment', Marketing Letters, Vol. 5, No. 2, pp.107-116.

Fishbein, M. and Ajzen, I. (1977) 'Attitude-behavior relations: a theoretical analysis and review of empirical research', Psychological Bulletin, Vol. 84, No. 5, p.888.

Gan, C., Wee, H.Y., Ozanne, L. and Kao, T.H. (2008) 'Consumers' purchasing behavior towards green products in New Zealand', Innovative Marketing, Vol. 4, No. 1, pp.93-102.

Ginsberg, J.M and Bloom, P.N. (2004) 'Choosing the right green marketing strategy', pp. 79-84, Sloan Management Review, Massachusetts Institute of Technology (MIT).

Gomon, S. (2005) The Influence of Promotional Brochures and Pricing Strategies on Consumer Purchase Decisions for Forest Stewardship Council Certified Hardwood Boards in Home Centers, MS thesis, Virginia Polytechnic Institute and State University, VA.

Gotschi, E., Vogel, S. and Lindenthal, T. (2007) High School Students' Attitudes and Behavior Towards Organic Products: Survey Results from Vienna, pp.1-23, Univ. für Bodenkultur, Department für Wirtschafts-und Sozialwiss., Inst. für Nachhaltige Wirtschaftsentwicklung.

Grunert, S.C. and Juhl, H.J. (1995) 'Values, environmental attitudes and buying of organic foods', Journal of Economic Psychology, Vol. 16, No. 1, pp.39-62.

Han, H., Hsu, L.T.J. and Sheu, C. (2010) 'Application of the theory of planned behavior to green hotel choice: Testing the effect of environmental friendly activities', Tourism Management, Vol. 31, No. 3, pp.325-334.

Han, H., Hsu, L.T.J., Lee, J.S. and Sheu, C. (2011) 'Are lodging customers ready to go green? An examination of attitudes, demographics and eco-friendly intentions', International Journal of Hospitality Management, Vol. 30, No. 2, pp.345-355.

Hartmann, P. and Apaolaza Ibáñez, V. (2006) 'Green value added', Marketing Intelligence and Planning, Vol. 24, No. 7, pp.673-680.

Holtzman, S. and Leich, C.M. (2014) Wittgenstein: to Follow a Rule, Vol. 4, Routledge, 2 Park Square, Milton Park, Abingdon, OXON.

Hoyer, W.D. and MacInnis, D.J. (2001) Consumer Behavior, 2nd ed., Houghton Mifflin Company, Boston.

Huang, C.L. (1996) 'Consumer preferences and attitudes towards organically grown produce', European Review of Agricultural Economics, Vol. 23, No. 3, pp.331-342.

Irland, L.C. (1993) 'Wood producers face green marketing era: environmentally sound products', Wood Technology, Vol. 120, No. 2, pp.34-36. 
Jain, S.K. and Kaur, G. (2004) 'Green marketing: an attitudinal and behavioral analysis of Indian consumers', Global Business Review, Vol. 5, No. 2, pp.187-205.

Kalafatis, S.P., Pollard, M., East, R. and Tsogas, M.H. (1999) 'Green marketing and Ajzen's theory of planned behavior: a cross-market examination', Journal of Consumer Marketing, Vol. 16, No. 5, pp.441-460.

Kaufmann, L., Kreft, S., Ehrgott, M. and Reimann, F. (2012) 'Rationality in supplier selection decisions: The effect of the buyer's national task environment', Journal of Purchasing and Supply Management, Vol. 18, No. 2, pp.76-91.

Kilbourne, W. and Pickett, G. (2008) 'How materialism affects environmental beliefs, concern, and environmentally responsible behavior', Journal of Business Research, Vol. 61, No. 9, pp.885-893.

Kim, Y. and Choi, S.M. (2005) 'Antecedents of green purchase behavior: an examination of collectivism, environmental concern and PCE', in Menon, G. and Rao, A.R. (Eds.): Advances in Consumer Research, pp.592-599, Duluth, MN, Association for Consumer Research.

Kumar, A., Kumar, K., Kaushik, N., Sharma, S. and Mishra, S. (2010) 'Renewable energy in India: current status and future potentials', Renewable and Sustainable Energy Reviews, Vol. 14, No. 8, pp.2434-2442.

Lee, K. (2008) 'Opportunities for green marketing: young consumers', Marketing Intelligence and Planning, Vol. 26, No. 6, pp.573-586.

Ling, K.C., Piew, T.H. and Chai, L.T. (2010) 'The determinants of consumers' attitude towards advertising', Canadian Social Science, Vol. 6, No. 4, pp.114-126.

Liska, A.E. (1984) 'A critical examination of the causal structure of the Fishbein/Ajzen attitude behavior model', Social Psychology Quarterly, Vol. 47, No. 1, pp.61-74.

Magnusson, M.K., Arvola, A., Koivisto Hursti, U.K., Åberg, L. and Sjödén, P.O. (2001) 'Attitudes towards organic foods among Swedish consumers', British Food Journal, Vol. 103, No. 3, pp.209-227.

Manaktola, K. and Jauhari, V. (2007) 'Exploring consumer attitude and behavior towards green practices in the lodging industry in India', International Journal of Contemporary Hospitality Management, Vol. 19, No. 5, pp.364-377.

Mayer, R., Ryley, T. and Gillingwater, D. (2012) 'Passenger perceptions of the green image associated with airlines', Journal of Transport Geography, Vol. 22, No. 1, pp.179-186.

McDaniel, S.W. and Rylander, D.H. (1993) 'Strategic green marketing', Journal of Consumer Marketing, Vol. 10, No. 3, pp.4-10.

Mostafa, M.M. (2007a) 'A hierarchical analysis of the green consciousness of the Egyptian consumer', Psychology and Marketing, Vol. 24, No. 4, pp.445-473.

Mostafa, M.M. (2007b) 'Gender differences in Egyptian consumers' green purchase behavior: the effects of environmental knowledge, concern and attitude', International Journal of Consumer Studies, Vol. 31, No. 3, pp.220-229.

Ng, S. and Paladino, A. (2009) 'Examining the influences of intentions to purchase green mobile phones among young consumers: an empirical analysis', in Conference Proceedings, ANZMAC, pp.1-8.

Pearson, A.W., Carr, J.C. and Shaw, J.C. (2008) 'Toward a theory of familiness: a social capital perspective', Entrepreneurship Theory and Practice, Vol. 32, No. 6, pp.949-969.

Pickett-Baker, J. and Ozaki, R. (2008) 'Pro-environmental products: marketing influence on consumer purchase decision', Journal of Consumer Marketing, Vol. 25, No. 5, pp.281-293.

Rahbar, E. and Abdul Wahid, N. (2011) 'Investigation of green marketing tools' effect on consumers' purchases behavior', Business Strategy Series, Vol. 12, No. 2, pp.73-83.

Ramayah, T., Lee, J.W.C. and Lim, S. (2012) 'Sustaining the environment through recycling: an empirical study', Journal of Environmental Management, Vol. 102, No. 1, pp.141-147. 
Ramayah, T., Lee, J.W.C. and Mohamad, O. (2010) 'Green product purchase intention: Some insights from a developing country', Resources, Conservation and Recycling, Vol. 54, No. 12, pp.1419-1427.

Rashid, N.R.N.A. (2009) 'Awareness of eco-label in Malaysia's green marketing initiative', International Journal of Business and Management, Vol. 4, No. 8, p.132.

Roberts, J.A. (1991) The Development of a Profile of the Socially Responsible Consumer for the 1990s and its Marketing Management and Public Policy Implications, Doctoral Thesis, Marketing Department, University of Nebraska, Lincoln, NE.

Roberts, J.A. and Bacon, D.R. (1997) 'Exploring the subtle relationships between environmental concern and ecologically conscious consumer behavior', Journal of Business Research, Vol. 40, No. 1, pp.79-89.

Saba, A. and Messina, F. (2003) 'Attitudes towards organic foods and risk/benefit perception associated with pesticides', Food Quality and Preference, Vol. 14, No. 8, pp.637-645.

Schultz, P.W., Zelezny, L. and Dalrymple, N.J. (2000) 'A multinational perspective on the relation between Judeo-Christian religious beliefs and attitudes of environmental concern', Environment and Behavior, Vol. 32, No. 4, pp.576-591.

Shabecoff, P. (1993) A Fierce Green Fire: The American Environmental Movement, Hill and Wang Publishers, New York, NY.

Sheltzer, L., Stackman, R.W. and Moore, L.F. (1991) 'Business environment attitudes and the new environmental paradigm', Journal of Environmental Education, Summer, Vol. 22, No. 4, pp.14-21.

Shepherd, G.J. and O'keefe, D.J. (1984) 'Separability of attitudinal and normative influences on behavioral intentions in the Fishbein-Ajzen model', The Journal of Social Psychology, Vol. 122, No. 2, pp.287-288.

Sheppard, B.H., Hartwick, J. and Warshaw, P.R. (1988) 'The theory of reasoned action: a meta-analysis of past research with recommendations for modifications and future research', Journal of Consumer Research, Vol. 15, No. 3, pp.325-343.

Sidique, S.F., Lupi, F. and Joshi, S.V. (2010) 'The effects of behavior and attitudes on drop-off recycling activities', Resources, Conservation and Recycling, Vol. 54, No. 3, pp.163-170.

Smith, S. and Paladino, A. (2010) 'Eating clean and green? Investigating consumer motivations towards the purchase of organic food', Australasian Marketing Journal (AMJ), Vol. 18, No. 2, pp.93-104.

Sparks, P. and Shepherd, R. (1992) 'Self-identity and the theory of planned behavior: assesing the role of identification with 'green consumerism', Social Psychology Quarterly, pp.388-399.

Straughan, R.D. and Roberts, J.A. (1999) 'Environmental segmentation alternatives: a look at green consumer behavior in the new millennium', Journal of Consumer Marketing, Vol. 16, No. 6, pp.558-575.

Sua, J.C.P., Wang, L. and Ho, J.C. (2012) 'The impacts of technology evolution on market structure for green products', Mathematical and Computer Modelling, Vol. 55, No. 3, pp.1381-1400.

Tanner, C. and Kast, S.W. (2003) 'Promoting sustainable consumption: determinants of green purchases by Swiss consumers', Psychology and Marketing, Vol. 20, No. 10, pp.883-902.

Thøgersen, J. and Zhou, Y. (2012) 'Chinese consumers' adoption of a 'green 'innovation the case of organic food', Journal of Marketing Management, Vol. 28, Nos. 3-4, pp.313-333.

Trafimow, D. and Finlay, K.A. (1996) 'The importance of subjective norms for a minority of people: Between-subjects and within subjects analyses', Personality and Social Psychologv Bulletin, Vol. 22, No. 8, pp.820-828.

Van Doorn, J. and Verhoef, P.C. (2011) 'Willingness to pay for organic products: differences between virtue and vice foods', International Journal of Research in Marketing, Vol. 28, No. 3, pp.167-180. 
Venkatesh, V. and Davis, F.D. (2000) 'A theoretical extension of the technology acceptance model: four longitudinal field studies', Management Science, Vol. 46, No. 2, pp.186-204.

Venkatesh, V., Morris, M.G., Davis, G.B. and Davis, F.D. (2003) 'User acceptance of information technology: toward a unified view', MIS Quarterly, Vol. 27, No. 3, pp.425-478.

Vermeir, I. and Verbeke, W. (2004) Sustainable Food Consumption: Exploring the Consumer Attitude-Behavior Gap, No. 4, p.268, Ghent University, WP.

Vermeir, I. and Verbeke, W. (2006) 'Sustainable food consumption: exploring the consumer 'attitude-behavioral intention' gap', Journal of Agricultural and Environmental Ethics, Vol. 19, No. 2, pp.169-194. 